\title{
Archetypes of Climate-Risk Profiles among Rural Households in Limpopo, South Africa ${ }^{\mathscr{O}}$
}

\author{
FIONA PAUMGARTEN \\ School of Animal, Plant and Environmental Sciences, University of the Witwatersrand, \\ Johannesburg, South Africa \\ BRUNO LOCATELLI \\ School of Animal, Plant and Environmental Sciences, University of the Witwatersrand, Johannesburg, \\ South Africa, and Forests and Societies, University of Montpellier, and CIRAD, Montpellier, \\ France, and Center for International Forestry Research, Lima, Peru \\ ED T. F. WITKOWSKI \\ School of Animal, Plant and Environmental Sciences, University of the Witwatersrand, \\ Johannesburg, South Africa
}

(Manuscript received 23 October 2019, in final form 31 March 2020)

\begin{abstract}
More frequent and intense climate hazards, a predicted outcome of climate change, are likely to threaten existing livelihoods in rural communities, undermining households' adaptive capacity. To support households' efforts to manage and reduce this risk, there is a need to better understand the heterogeneity of risk within and between communities. The Intergovernmental Panel on Climate Change revised their climate vulnerability framework to incorporate the concept of risk. This study contributes toward the operationalization of this updated framework by applying a recognized methodology to the analysis of the climate-related risk of rural households. Using a mixed-method approach, including a cluster analysis, it determined and assessed archetypical patterns of household risk. The approach was applied to 170 households in two villages, in different agroecological zones, in the Vhembe District Municipality of South Africa's Limpopo Province. Six archetypical climate-risk profiles were identified based on differences in the core components of risk, namely, the experience of climate hazards, the degree of exposure and vulnerability, and the associated impacts. The method's application is illustrated by interpreting the six profiles, with possible adaptation pathways suggested for each. The archetypes show how climate-related risk varies according to households' livelihood strategies and capital endowments. There are clear site-related distinctions between the risk profiles; however, the age of the household and the gender of the household head also differentiate the profiles. These different profiles suggest the need for adaptation responses that account for these site-related differences, while still recognizing the heterogeneity of risk at the village level.
\end{abstract}

\section{Introduction}

Climate change impacts are expected to vary across regions, influenced by the hazards experienced, the degree of exposure, and the vulnerability of the natural

Supplemental information related to this paper is available at the Journals Online website: https://doi.org/10.1175/WCAS-D-190134.s1.

Corresponding author: Fiona Paumgarten, fi.paumgarten@ gmail.com and human systems exposed (Pachauri et al. 2014). Certain populations and sectors are likely to be harder hit, particularly where natural-resource-based systems support livelihoods (Kok et al. 2016). Dryland areas, including much of South and southern Africa, already face challenges that create vulnerable socioecological systems (Safriel and Adeel 2008; Blackie et al. 2014). These include marginal ecosystems with low agroecological potential under pressure from multiple users; low, seasonal, and unreliable rainfall; poor infrastructure and public services; poor governance; a marginalized population; limited opportunities for alternative 
livelihoods; low literacy rates; food insecurity; and the prevalence of chronic diseases (e.g., HIV/AIDS) (Reynolds et al. 2007; Safriel and Adeel 2008; O'Brien et al. 2009; Sietz et al. 2011). Climate change is expected to exacerbate these vulnerability-creating mechanisms, undermining efforts to achieve sustainable development goals (Pachauri et al. 2014; Sietz et al. 2017). Rural households in these areas, who tend to be insufficiently insured, face the risk of increasing vulnerability unless their capacity to cope with, and adapt to, climate change improves (Günther and Harttgen 2009; Pachauri et al. 2014).

Vulnerability is multidimensional, varying temporally and spatially, affected by various environmental, economic, political, and institutional conditions (Skoufias 2003; Vogel and O'Brien 2004; Günther and Harttgen 2009; Ahsan and Warner 2014). This makes assessing vulnerability challenging (Luers et al. 2003). However, understanding the ways in which societies and ecosystems are vulnerable is important for the design, implementation, and monitoring of measures to reduce vulnerability (Adger et al. 2004; Vincent 2007; Kok et al. 2016). Responding to this challenge, various assessment studies have sought to understand the drivers and heterogeneity of vulnerability, generally and within the climate change space, with each approach contributing to the enhancement of the methodology (e.g., Leichenko and O'Brien 2002; Füssel and Klein 2006; Birkmann 2007; Sallu et al. 2010; Kok et al. 2016). For example, indicatorbased approaches, which construct single vulnerability and adaptive-capacity indices (e.g., Luers et al. 2003; Hahn et al. 2009; Gbetibouo et al. 2010; Ahsan and Warner 2014), reduce complexity but make drawing conclusions on specific intervention points difficult. Conversely, using disaggregated indicators maintains the data's richness but can result in too many indicator combinations to analyze systematically (Adger et al. 2004; Ahsan and Warner 2014; Kok et al. 2016). Recently, cluster-based approaches have been used to identify typical patterns of vulnerability (Jäger et al. 2007; Sietz et al. 2012, 2017; Kok et al. 2016; Vidal Merino et al. 2019), guided by indications of certain distinct, recurring vulnerability-creating mechanisms (Reynolds et al. 2007; Safriel and Adeel 2008; Sietz et al. 2011). As a method, cluster-based approaches reduce complexity by revealing a limited number of typical, recurrent indicator combinations, or clusters, which can be interpreted systematically (Sietz et al. 2011, 2012; Kok et al. 2010, 2016).

Cluster-based approaches can be used across domains, including Earth, life, social, behavioral, information and policy sciences, and medicine and engineering (Anderberg 1973). At the rural household level, cluster analysis has been used, for example, to construct a typology of households participating in improved crop management in Malawi (Orr and Jere 1999), and to explore the poverty profiles of households in postconflict Rwanda (Ansoms and McKay 2010). More recently, cluster analysis has been applied to studies of livelihood vulnerability or climate change adaptation (Oberlack et al. 2019). For example, to identify archetypes of vulnerability to weather extremes in Peru (Sietz et al. 2012; Vidal Merino et al. 2019) and to global change in dryland systems (Kok et al. 2010, 2016; Sietz et al. 2011, 2017). These archetypes are generally defined as representations of factors and processes that repeat in socialecological systems, or of patterns of human-nature interactions (Sietz et al. 2019). By keeping the selected indicators disaggregated, cluster/archetype analysis allows for discussions on the factors that shape vulnerability and risk of the selected system (Kok et al. 2016; Sietz et al. 2017). Our study aims to build on these existing analyses, using a cluster-based approach to assess climate-related vulnerability and risk at the household level, in two rural villages in different agroecological zones in South Africa.

Given the heterogeneity of rural communities, different households are likely to experience varying degrees of vulnerability to climate change, with their adaptive capacity influenced by the resources at their disposal [Department for International Development (DFID) 1999; Vogel and O'Brien 2004; Vincent 2007; Eakin and Bojórquez-Tapia 2008; Sietz et al. 2012]. Using combinations of indicators related to climate hazards, exposure, vulnerability, and impacts, we apply a cluster analysis to determine whether there are differentiated, archetypical climate-risk profiles. We use a conceptual framework that combines the Intergovernmental Panel on Climate Change's (IPCC) most recent framework on vulnerability and climate-related risk (2014) with the Sustainable Livelihoods Framework (SLF) (DFID 1999) to define and quantify vulnerability. By identifying and assessing these climate-risk profiles, we aim to improve the understanding of the heterogeneity of the climate-related risk among rural households in dryland systems. We explore the profiles to determine if they provide lessons for adaptation responses, based on the assumptions that (i) if the profiles differ substantially between the two sites, then responses need to be site-specific; (ii) if they are similar, then responses can be applied more broadly across sites but may have to be adjusted for specific household characteristics.

\section{Study area}

The research was conducted in the Vhembe District Municipality of South Africa's Limpopo Province, one of the country's poorest provinces (Statistics South Africa 2014). According to recent national census results (2011), 


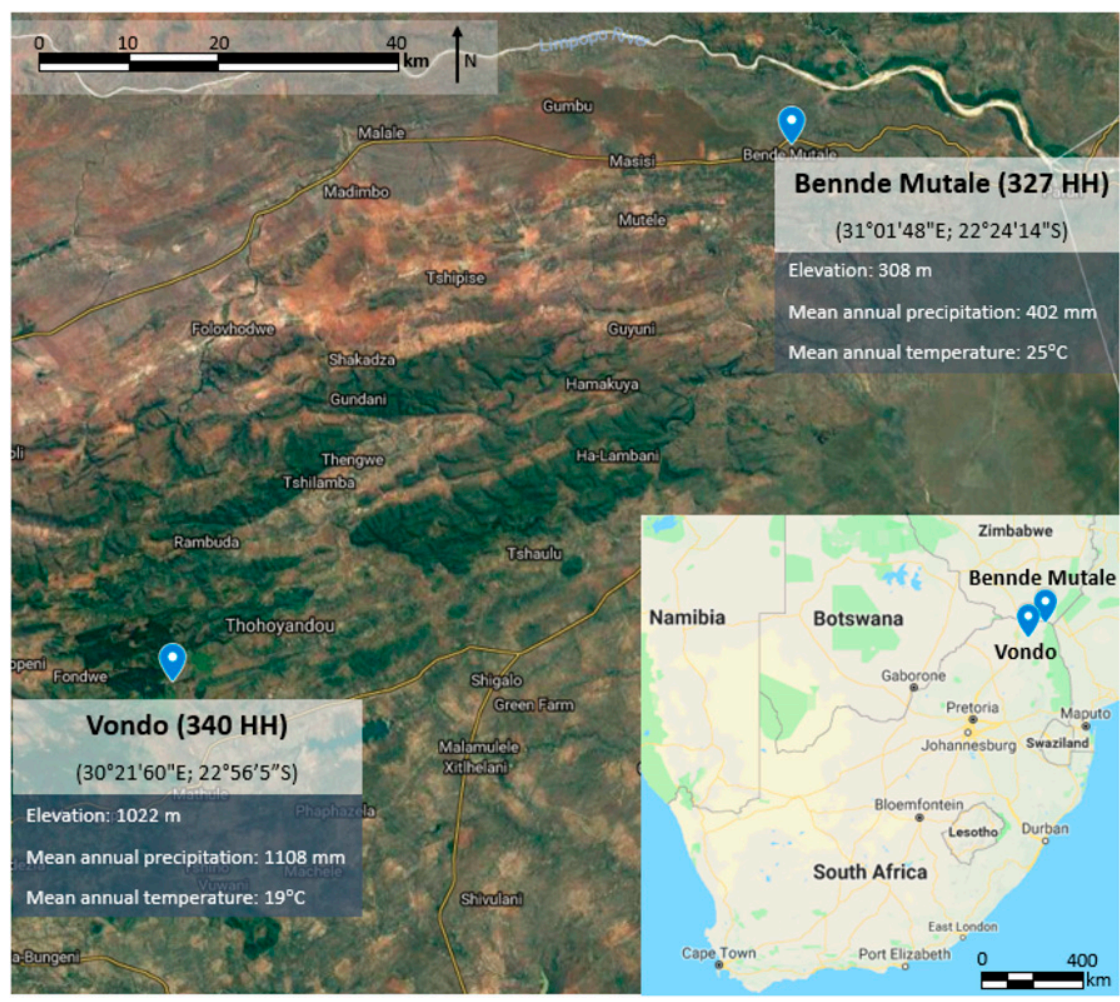

FIG. 1. Location and details of the two study sites: Vondo (wet site) and Bennde Mutale (dry site) (Source: Google Earth).

this area faces ongoing challenges with poor service provision and development, high dependency ratios and youth unemployment rates, and low levels of education (Statistics South Africa 2014). Government pension and social grants and migrant remittances make an important contribution to household income, with limited local employment opportunities (Venter and Witkowski 2013; Statistics South Africa 2014; Ofoegbu et al. 2016). On average, $54 \%$ of households are female headed, a legacy of South Africa's former homeland system and a reflection of the ongoing reliance on migrant labor (Statistics South Africa 2014). Given the high levels of engagement in subsistence and commercial land-based livelihood strategies, climate change is likely to adversely affect the province's inhabitants (Turpie and Visser 2013; Thivhafuni 2015).

We considered rural households in the villages of Bennde Mutale and Vondo, located approximately $90 \mathrm{~km}$ apart, separated by the Soutpansberg mountain range (Fig. 1). Bennde Mutale, in the Mutale local municipality, is separated from the Limpopo River (the border with Zimbabwe) by the Madimbo Military Corridor. The site is further delineated by the Kruger National Park (to the east), the Mutale River (south), and communal rangelands (west). Vondo, in the Thulamela local municipality, lies to the north of the Mutshindudi River and is surrounded by government-owned pine and tea plantations and neighboring communities. The site selection was based primarily on differences in mean annual precipitation (MAP) and agroecological conditions, with Bennde Mutale located in an arid agroecological zone (AEZ) and Vondo in a semiarid zone (International Food Policy Research Institute 2015). The dominant vegetation types in Bennde Mutale include Musina Mopane Bushveld and Makuleke Sandy Bushveld, while Soutpansberg Mountain Bushveld is dominant in Vondo (Mucina and Rutherford 2011). Both sites have a summer rainy season and a cooler, dry winter, but Vondo receives almost 3 times Bennde Mutale's annual precipitation and is about $6^{\circ} \mathrm{C}$ cooler (Funk et al. 2015). Given these differences, Bennde Mutale is henceforth referred to as the "dry site" and Vondo as the "wet site."

In addition to these biophysical differences, communities were chosen where most households display some level of dependence on land-based livelihoods and natural resources. Willingness to participate in the research was another influencing factor.

Households in both sites engage in arable agriculture, animal husbandry, and the use and sale of nontimber forest products (NTFPs). Arable agriculture is more 
prevalent in the wet site. According to respondents, there are constraints to these land-based livelihoods including seasonality, climate hazards, pests and diseases, overharvesting and overgrazing, limited land, and limited access to markets and extension support (information from community workshops). These constraints, and households' increasing integration into the cash economy, make it difficult to depend exclusively on subsistence-level, landbased livelihoods. Households seek to diversify although local employment opportunities are limited (community workshops). Although the dry site is more remote, its proximity to the national park and various tourism facilities provides opportunities for local employment.

The nearest, large commercial and administrative center to both sites is Thohoyandou (15 and $95 \mathrm{~km}$ from the wet and dry sites, respectively). This limits access to services (e.g., banks, formal credit institutions, extension support) and to input and output markets. The wet site is difficult to access during the summer when heavy rains make the village's steep, dirt roads impassable. Neither village has a secondary school or clinic. People rely on traditional healers and a mobile clinic. Poor access to healthcare, an increase in chronic diseases (e.g., diabetes and HIV/AIDS), and food insecurity were associated with declining well-being (community workshops). Households rely on communal taps and natural water sources for consumption, irrigation, and livestock. The amount and quality of water is affected by multiple users, the intermittent supply from the communal taps, and the seasonal availability of natural water sources. Most households have electricity, but fuelwood remains important for cooking, with overharvesting a concern.

Floods and drought are experienced in both sites, although respondents indicated that these are more severe in the dry site (community workshops). Floods are associated with erosion and landslides, crop and livestock losses, and increases in waterborne diseases (e.g., malaria and cholera). Damage to infrastructure, including houses, fences, irrigation equipment, electricity poles, roads, and bridges, was also reported with respondents attributing this to poor planning and the use of inferior construction materials. Drought is also associated with crop and livestock losses, resulting in hunger and malnutrition. Natural water sources dry up and NTFP availability declines.

\section{Methods}

\section{a. The conceptual framework}

The IPCC's climate vulnerability framework has been modified to include the concept of risk, shifting from the previous focus on vulnerability and its core components (i.e., exposure, sensitivity, and adaptive capacity) (Pachauri et al. 2014; Kok et al. 2016). Risk involves the potential for impacts resulting from the interaction of climate-related hazards with the vulnerability and exposure of human and natural systems, with exposure now described as a separate component (Pachauri et al. 2014). This revised framework has rarely been applied at the household level (but see Karim 2018). We combine this framework with the SLF (DFID 1999) and develop a conceptual framework for the assessment of household-level, climate-related risk. After defining and measuring indicators for the framework's core components, we use a cluster analysis to explore archetypical household-level, climate-risk profiles (Kok et al. 2016) (Fig. 2, Table 1).

Regarding the core components, for hazards (i.e., natural- or human-induced, climate-related physical events or trends that may result in impacts) we focused on floods and drought (Pachauri et al. 2014). For exposure we considered households' involvement in arable agriculture and animal husbandry, with exposure implying that households have livelihood activities and assets that could be adversely affected by hazards (Pachauri et al. 2014). We considered impacts on both agriculture and animal husbandry as well as those to household infrastructure and/or major assets, with the latter associated with the experience of floods. Vulnerability, defined as "the propensity to be adversely affected," encompasses households' susceptibility to harm and their capacity to cope and adapt (Pachauri et al. 2014, p. 128). Here we focused on households' adaptive capacity, using their access to capital endowments (as outlined in the SLF) as an indicator of their ability to cope with and manage risk (Reid and Vogel 2006; Pachauri et al. 2014; de Jalón et al. 2018; Vidal Merino et al. 2019).

\section{b. Data collection}

Data were collected using a mixed-method approach, including a semistructured household survey and a participatory rural appraisal (PRA). Key informant interviews were conducted with local elders, traditional leaders, local farmers, livestock owners, traditional healers, and the extension officers responsible for each site. These interviews, and personal observations, were intended to support the survey and PRA data. Prior to the initiation of the fieldwork, a team of enumerators/facilitators was trained on the methods, which allowed for the interviews and community workshops to be conducted in the local language. An introductory workshop was held in each village. Free, prior, and informed consent was received from all participants and anonymity was assured.

The survey was administered to 170 randomly selected households, 85 per village, a quarter of each village's total number of households (see "Supplemental Material 1" section in the online supplemental material). The interviews were conducted with a well-informed, adult household member, preferably the household 


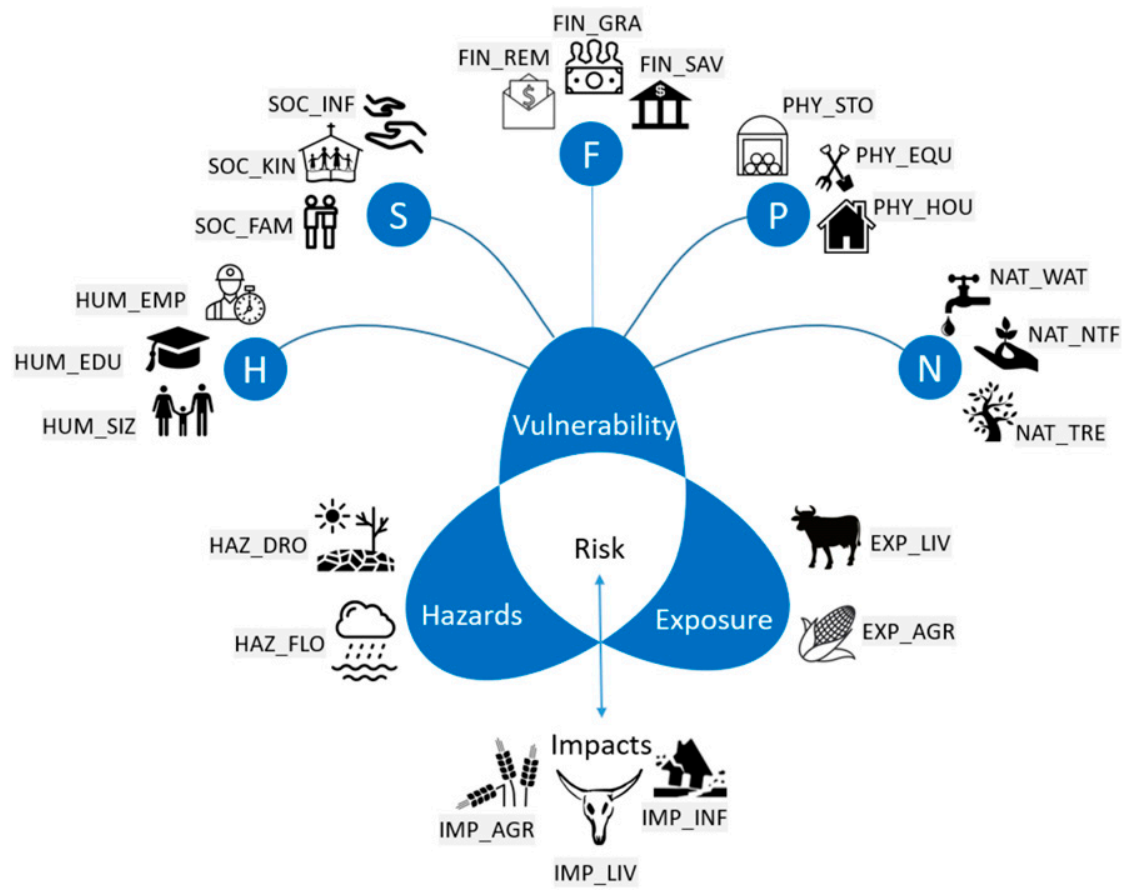

FIG. 2. Conceptual framework for the assessment of household-level, climate-related risk, combining (center) the Pachauri et al. (2014) framework and (top) the Sustainable Livelihoods Framework (DFID 1999). See Table 1 for variable codes (e.g., PHY_EQU = Physical capital: Equipment). H, S, F, P, and N stand for Human, Social, Financial, Physical, and Natural capital, respectively.

head (whether male or female). For the survey design we drew from the SLF (DFID 1999), the Poverty Environment Network (Wunder et al. 2014), the Livelihood Vulnerability Index (Hahn et al. 2009), and similar vulnerability assessment studies (e.g., Vincent 2007; Eakin and Bojórquez-Tapia 2008; Ahsan and Warner 2014). Following a livelihoods approach, data were collected on households' sociodemographic and socioeconomic characteristics, their engagement in off-farm and land-based livelihoods, their experience of multiple stressors (including climate-related hazards), and the coping strategies used in response to these.

The PRA was conducted to establish an understanding of the socioeconomic environment and overall vulnerability context of the sites. Community members were invited to a series of workshops with the initial participants invited to subsequent workshops to build on discussions. The exercises conducted drew from the participatory vulnerability and capacity analysis methodologies developed by Dazé et al. (2009) and Turnbull and Turvil (2012). These apply a climate lens to livelihoods' analyses, allowing communities to identify and assess their vulnerabilities and adaptive capacity to climaterelated hazards (Turnbull and Turvil 2012). The exercises explored annual cycles in livelihood strategies and resource availability and identified major events that have affected the communities. They aided discussions on the impacts of floods and drought, on how people coped with these previously, and on possible responses to reduce future impacts.

Based on the results of the survey and the PRA, and taking the existing literature into consideration, we defined indicators for the components of the conceptual framework. The mix of quantitative household-level data and qualitative community-level data supported the interpretation of the results, providing a more comprehensive understanding of climate risk within and between the sites (Vidal Merino et al. 2019).

\section{c. The selection and definition of indicators}

We selected 22 indicators, and used data collected during the household survey, to represent the framework's core components (i.e., the risk dimensions) (Fig. 2, Table 1). We selected two indicators for hazards related to households' self-reported experience of floods and drought. Given their proximity, the sites have experienced many of the same regional flood and drought events, although households may have experienced them differently. For example, tropical cyclones caused flooding in 2000 and 2013, while El Niño caused 
TABLE 1. Description of indicators used in the cluster analysis, grouped by the risk dimensions of the Pachauri et al. (2014) framework (see Fig. 2), with households' access to different capital endowments [as defined in the SLF (DFID 1999)] used as an indicator of households' adaptive capacity (and therefore their vulnerability). The measurements (range of observed values) are taken from the household survey.

\begin{tabular}{|c|c|c|c|}
\hline Risk dimension & Indicator description & Abbreviation & Measurement (range of observed values) \\
\hline \multirow[t]{2}{*}{ Hazards } & $\begin{array}{l}\text { Drought events faced by the } \\
\text { household }\end{array}$ & HAZ_DRO & $\begin{array}{l}\text { The number of major drought events reported when asked to } \\
\text { mention the year the worst and second-worst drought events } \\
\text { were experienced (0-2). }\end{array}$ \\
\hline & $\begin{array}{l}\text { Flood events faced by the } \\
\text { household }\end{array}$ & HAZ_FLO & $\begin{array}{l}\text { The number of major flood events reported when asked to } \\
\text { mention the year the worst and second-worst flood events } \\
\text { were experienced }(0-2) \text {. }\end{array}$ \\
\hline \multirow[t]{2}{*}{ Exposure } & $\begin{array}{l}\text { Households' involvement in } \\
\text { agriculture }\end{array}$ & EXP_AGR & $\begin{array}{l}\text { The practice of agriculture in a home garden or field (1) or both } \\
\text { (2) (0-2). }\end{array}$ \\
\hline & $\begin{array}{l}\text { Households' involvement in } \\
\text { livestock raising }\end{array}$ & EXP_LIV & $\begin{array}{l}\text { The total number of livestock units owned (using equivalence } \\
\text { factors between animals), log transformed [FAO } 2003 \\
\text { (adapted by Chilonda and Otte 2006)]. }\end{array}$ \\
\hline \multirow[t]{3}{*}{ Impacts } & Impacts on agriculture & IMP_AGR & $\begin{array}{l}\text { The occurrence of crop failure (1), crop pests and disease (1), or } \\
\text { both (2) in the last five years }(0-2) \text {. }\end{array}$ \\
\hline & Impacts on livestock & IMP_LIV & $\begin{array}{l}\text { The occurrence of livestock loss }(1) \text {, livestock pests and disease } \\
\text { (1), or both (2) in the last five years }(0-2) \text {. }\end{array}$ \\
\hline & Impacts on infrastructure & IMP_INF & $\begin{array}{l}\text { The occurrence of loss of/damage to infrastructure or major } \\
\text { assets (e.g., house, agricultural implements, etc.) (1), other } \\
\text { damage from natural disasters (1), or both (2) in the last five } \\
\text { years (0-2) }\end{array}$ \\
\hline \multirow[t]{8}{*}{ Vulnerability } & Human capital: Household size & HUM_SIZ & $\begin{array}{l}\text { The number of people in the household, full-time residents } \\
\text { sharing a kitchen, excluding migrants (1-14). }\end{array}$ \\
\hline & Human capital: Education & HUM_EDU & $\begin{array}{l}\text { The number of years of school education of the household head } \\
(0-13) \text {. }\end{array}$ \\
\hline & $\begin{array}{l}\text { Human capital: Off-farm } \\
\text { workforce }\end{array}$ & HUM_EMP & $\begin{array}{l}\text { The number of types of off-farm jobs in the household, } \\
\text { including formal and informal jobs and self-employment } \\
\text { (0-2) (Vidal Merino et al. 2019). }\end{array}$ \\
\hline & Financial capital: Remittances & FIN_REM & $\begin{array}{l}\text { The frequency of migrant remittances received }[0=\text { never, } \\
1=\text { infrequently }(1-2 \text { times per year or only when asked), } \\
2=\text { every month]. Households receiving regular remittances } \\
\text { (i.e., off-farm income) are considered to have higher financial } \\
\text { capital than those receiving intermittent support } \\
\text { (DFID 1999). }\end{array}$ \\
\hline & $\begin{array}{l}\text { Financial capital: Government } \\
\text { pension and social grants }\end{array}$ & FIN_GRA & $\begin{array}{l}\text { The total monthly monetary value of government pension and } \\
\text { social grants (i.e., old age, child-care, and disability grants), } \\
\text { normalized by household size (i.e., divided by the number of } \\
\text { household members: } 1 \text { for adult, } 0.5 \text { for child) (ZAR } 0-1520 \text { ), } \\
\text { log transformed. }\end{array}$ \\
\hline & $\begin{array}{l}\text { Financial capital: Formal } \\
\text { savings }\end{array}$ & FIN_SAV & $\begin{array}{l}\text { The number of formal savings: bank or post office account, and } \\
\text { crop and weather insurance (0-2). These savings provide a } \\
\text { coping option and reflect households' ability to accumulate } \\
\text { capital (Gautam and Andersen 2016; Vidal Merino } \\
\text { et al. 2019). }\end{array}$ \\
\hline & Natural capital: Access to water & NAT_WAT & $\begin{array}{l}\text { The number of water sources used for irrigation, livestock, and } \\
\text { domestic uses (1-3). Access to a diversity of sources } \\
\text { (including community and household taps and natural water } \\
\text { sources such as rivers and springs) may ensure supply. }\end{array}$ \\
\hline & Natural capital: Use of NTFPs & NAT_NTF & $\begin{array}{l}\text { The number of activities related to NTFPs [i.e., either no } \\
\text { activities (0) and/or the collection, use, and/or sale (1-3)]. } \\
\text { NTFPs included fuelwood, wild foods [i.e., edible herbs and } \\
\text { fruit and bushmeat (including fish)], medicinal plants, wood, } \\
\text { and fibers. The use and sale of NTFPs reflects households' } \\
\text { traditional ecological knowledge, access to labor, access to } \\
\text { collection areas and markets, etc. (McSweeney 2005; Reid } \\
\text { and Vogel 2006; Paumgarten and Shackleton 2011). }\end{array}$ \\
\hline
\end{tabular}


TABLE 1. (Continued)

\begin{tabular}{|c|c|c|c|}
\hline Risk dimension & Indicator description & Abbreviation & Measurement (range of observed values) \\
\hline & $\begin{array}{l}\text { Natural capital: Tree } \\
\text { ownership }\end{array}$ & NAT_TRE & $\begin{array}{l}\text { The number of categories of edible fruit trees cultivated and/or } \\
\text { maintained in the household lands [i.e., either none, or only } \\
\text { indigenous/exotic, or both indigenous and exotic }(0-2)] \text {. }\end{array}$ \\
\hline & $\begin{array}{l}\text { Physical capital: Storage } \\
\text { capacity }\end{array}$ & PHY_STO & $\begin{array}{l}\text { The number of resources (water, crops, seeds, NTFPs) that the } \\
\text { household can store (1-4), reflecting households' ownership } \\
\text { of storage facilities and their ability to produce/collect a } \\
\text { surplus for when needed; e.g. wild foods can be stored as a } \\
\text { buffer for seasonal crop shortfalls. }\end{array}$ \\
\hline & $\begin{array}{l}\text { Physical capital: } \\
\text { Equipment owned }\end{array}$ & PHY_EQU & $\begin{array}{l}\text { The estimated value of equipment (i.e., disposable assets } \\
\text { including stove, refrigerator, radio, cell phone, television, car, } \\
\text { bike, tractor, wheelbarrow, cart, plough, chainsaw, water } \\
\text { pump, solar panel) (ZAR 53,000-1,830,000), log } \\
\text { transformed. These assets reflect households' economic } \\
\text { welfare (Vidal Merino et al. 2019). The equipment may } \\
\text { contribute toward production activities (e.g., ploughs), } \\
\text { improve households' access to information (e.g., cell } \\
\text { phones), and could be sold as a coping strategy (DFID 1999; } \\
\text { de Jalón et al. 2018). }\end{array}$ \\
\hline & Physical capital: House type & PHY_HOU & $\begin{array}{l}\text { The resistance of house walls and roof reflected by the type of } \\
\text { construction materials used ( } 1 \text { if concrete walls, }+1 \text { if } \\
\text { nonreed/-thatch/-grass roof) ( } 0-2) \text {. The use of modern (i.e., } \\
\text { nontraditional) building materials reflects households' ability } \\
\text { to construct homes that are more resistant to damage from } \\
\text { floods, strong winds, etc. (Vincent 2007; Ahsan and } \\
\text { Warner 2014). }\end{array}$ \\
\hline & $\begin{array}{l}\text { Social capital: Extended family } \\
\text { support in the village }\end{array}$ & SOC_FAM & $\begin{array}{l}\text { The strength of family-based kinship networks in the village } \\
\text { ( } 1 \text { if there is family support in the village. }+1 \text { if it has provided } \\
\text { help in the last two years) (0-2). }\end{array}$ \\
\hline & $\begin{array}{l}\text { Social capital: Membership in } \\
\text { associations and groups }\end{array}$ & SOC_KIN & $\begin{array}{l}\text { The number of memberships in local associations and groups } \\
\text { (i.e., church, burial society, agricultural cooperative, or } \\
\text { other) }(0-4) \text {. }\end{array}$ \\
\hline & $\begin{array}{l}\text { Social capital: Membership in } \\
\text { informal saving schemes }\end{array}$ & SOC_INF & $\begin{array}{l}\text { The number of informal savings schemes: Savings from burial } \\
\text { societies and/or stovkels and saving clubs (rotating and } \\
\text { accumulating schemes) (0-2). }\end{array}$ \\
\hline
\end{tabular}

droughts in the early 1980s and 1990s. South Africa's most recent drought occurred after the fieldwork. For exposure, we also selected two indicators, namely, households' involvement in arable agriculture and animal husbandry. For impacts we selected three indicators related to the self-reported occurrence of impacts on agriculture, livestock, and/or household infrastructure and assets. We focused on impacts that required a response by the household, although the indicators reflect only the occurrence of an impact, not the degree of loss. The latter would require further research. Infrastructure damages, including damage to fences and livestock enclosures, irrigation equipment, and storage facilities and their contents (including seed stocks, food, etc.), may aggravate the direct impacts on agriculture and animal husbandry. The indicators for hazards, exposure and impacts were assumed to be positively correlated with risk.

For vulnerability, we selected 15 indicators grouped by capital type [i.e., human, financial, natural, physical, and social capital (DFID 1999)], with three indicators per type (Fig. 2, Table 1). These capitals are assumed to reflect households' adaptive capacity and are therefore negatively correlated with risk (Ahsan and Warner 2014). We focused on household-level indicators, with households with limited capital considered to be more vulnerable (Cooper et al. 2008; Heltberg et al. 2009; Vidal Merino et al. 2019).

Households' human capital is expressed as a function of household size, education of the head, and members' engagement in local, off-farm employment. High human capital reflects households' labor and skills and ability to diversify into less climate-sensitive, off-farm livelihoods (DFID 1999; Dercon 2002; Sietz et al. 2012). Labor availability has also been linked to households' ability to turn to labor-intensive coping options including a reliance on NTFPs [e.g., as noted by McSweeney (2005) in response to hurricane-related losses in Honduras]. Financial capital, often described as the capital type least available to the poor, is expressed as a function of households' access to migrant remittances, government 
pension and social grants, and formal cash savings (DFID 1999; Reid and Vogel 2006; Paumgarten and Shackleton 2011). For natural capital, which provides livelihood and coping options, we used indicators related to households' access to multiple water sources, their use and sale of NTFPs, and their ownership of private tree crops (DFID 1999). Physical capital is reflected by households' capacity to store resources (including water, NTFPs, crops, and seed), the estimated value of household equipment, and households' use of modern (i.e., nontraditional) building materials (DFID 1999; Ahsan and Warner 2014; Vidal Merino et al. 2019). Households' social capital is expressed by their available kinship networks, including family networks within the village, and households' membership in local associations and groups (Paumgarten and Shackleton 2011; Ahsan and Warner 2014). The latter is correlated with households' participation in informal savings schemes, the third selected indicator of social capital. The number of memberships held is taken as representative of the strength of the social capital (Vincent 2007). Social capital provides coping and adaptation options and allows for the accumulation of savings (particularly in the absence of formal savings institutions) (Paumgarten and Shackleton 2011). It is important for poor households with limited alternative insurance options (DFID 1999; Pelling and High 2005; Vincent 2007).

Variables related to the location of the household (i.e., site), the age of the household, and the gender of the household head were not directly assigned indicators as they could not be directly linked to the household capital profiles. However, these variables were considered when describing the clusters. With respect to the age of the household, we refer to the more wellestablished households as "older" households, while those more recently established households are described as "newer" households

\section{d. Cluster analysis}

We applied a clustering procedure, as described by Janssen et al. (2012) and Kok et al. (2010, 2016), to identify archetypical patterns or profiles of risk, based on recurrent indicator combinations. This cluster-based approach was previously applied by Sietz et al. (2011, 2012, 2017), Kok et al. (2010, 2016) and Vidal Merino et al. (2019). The approach combines a hierarchical ( $h$-clust) and partitioning ( $k$-means) clustering algorithm, with the data first transformed to values between 0 and 1 with a minimum-maximum (min-max) normalization (see "Supplemental Material 2" section; Fig. SM2.1). While the $k$-means algorithm efficiently partitions the data into $k$ groups, its outcome is sensitive to initialization. We used the $h$-clust algorithm (Ward's method) to define the initial conditions (i.e., the cluster centers) for the $k$-means. We resampled the initial dataset, randomly sampling the same number of observations with replacement, before rerunning the algorithms. By repeating this process, we established a consistency measure enabling us to identify the optimal number of clusters for analysis (Sietz et al. 2012). Although the partition with three clusters yielded the highest consistency measure $(88 \%)$, it was not very informative, with the clusters possibly aggregating too diverse a selection of households (see "Supplemental Material 2"; Fig. SM2.2). For partitions of 5-10 clusters, the consistency measure varied between $60 \%$ and $65 \%$ with no marked local maximum. Therefore, using the MClust function in $\mathrm{R}$, we applied hierarchical clustering for parameterized Gaussian mixture models, obtaining two optima at $k=6$ and $k=11$ (see "Supplemental Material 2"; Fig. SM2.3). We found the interpretation of six clusters to be the most informative.

To interpret the six clusters, we observed the mean values of the selected indicators and compared pairs of clusters using Tukey Honest Significant Differences (TukeyHSD function in R). For each indicator, we identified the clusters with the largest and smallest means, or a mean value that did not differ significantly from the largest or smallest (see "Supplemental Material 2"; Fig. SM2.4). The clusters were interpreted qualitatively, using results from the fieldwork. The limited number of representative indicator combinations makes this qualitative interpretation possible (Sietz et al. 2011).

\section{Results}

Of the six clusters categorized according to their respective risk profiles, cluster 2 was the largest, representing $27 \%$ of the sampled households (Fig. 3). This was followed by cluster 4 (19\%), then cluster 1 (16\%). Clusters 3 and 6 both represented $13 \%$ of households. Cluster 5 represented $12 \%$.

\section{Interpretation of households' climate-risk profiles}

Some indicators had limited influence in defining the clusters [i.e., they had a medium value (see the white boxes in Fig. 3)]. These included households' (i) access to government pension and social grants and formal savings (financial capital), (ii) available storage facilities (physical capital), and (iii) access to family-based kinship networks (social capital). Membership in associations and groups included informal savings schemes, with these social capital indicators therefore correlated. The experience of drought, as a hazard indicator, also had limited influence, with floods having been experienced more recently (in 2000 and 2013). 


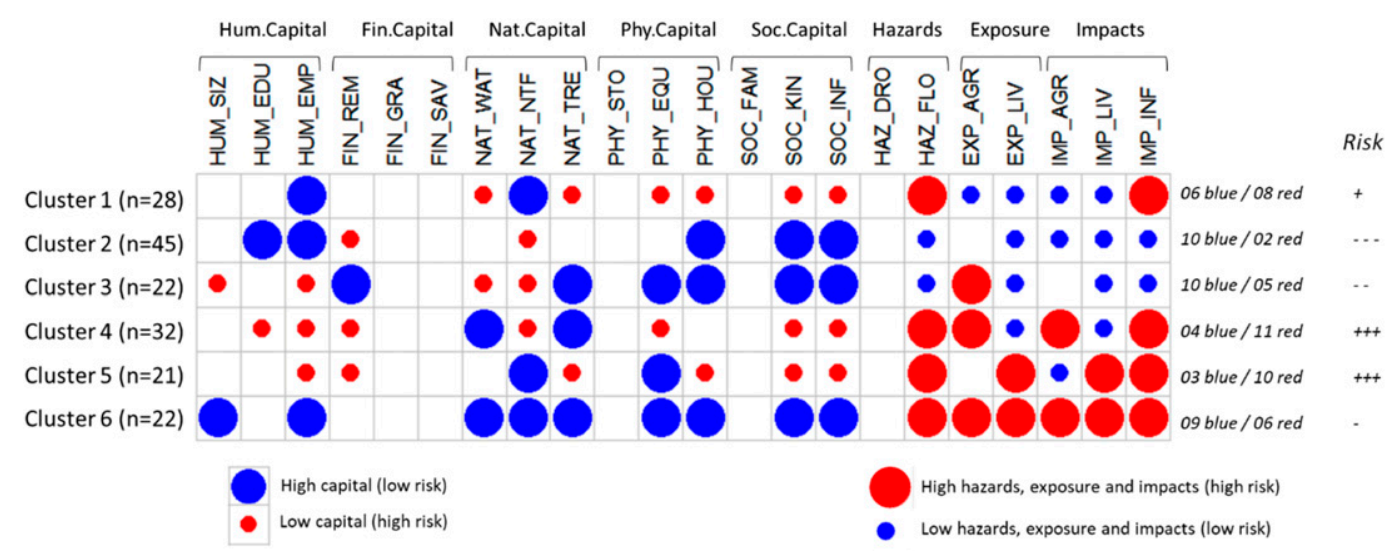

FIG. 3. Household clusters (rows) and indicators (columns), with large circles representing clusters with the largest means (or means not significantly different from the largest). The inverse applies to the small circles. White cells indicate a medium value. Assuming a negative correlation between capital and risk, the large blue circles represent high capital and low risk. The small red circles represent the inverse. For hazards, exposure, and impact, the large red circles represent indicators positively correlated with risk. The small blue circles represent low risk. The risk scores, with +++ reflecting the highest risk and --- reflecting the lowest risk, represent the difference between the number of blue and red circles. See Table 1 for variable codes (e.g., PHY_EQU = Physical capital: Equipment).

The different clusters are described and interpreted in the following sections.

\section{1) CAPITAL-CONSTRAINED HOUSEHOLDS WITH LIMITED PRODUCTION IMPACTS BUT MODERATE RISK}

Cluster 1 represented poor, off-farm households who faced moderate risk related to their capital constraints, despite low exposure and impacts given their limited involvement in land-based livelihoods. Most $(86 \%)$ of these households were in the dry site. They were newer households, possibly still building their capital portfolio.

These households had high human capital reflected in their access to employment, although this may involve unskilled work as laborers in government's Extended Public Works Program and the nearby conservation areas and tourism facilities. Skilled positions existed as national park field rangers, but local opportunities were limited. These households had low natural capital related to the limited water sources used, although their water requirements may be lower given their limited involvement in land-based livelihoods. They had low natural capital in the form of private tree crops with the drier conditions hindering the cultivation of exotic fruit trees (e.g., Mangifera indica) (community workshops). They had high natural capital related to NTFPs, however, as households in both sites used NTFPs (e.g., over $80 \%$ used wild foods and fuelwood), the sale of NTFPs is probably the distinguishing factor here. These households had low physical capital, with more traditionally constructed homes and limited household equipment.
Households had homes constructed from mud bricks and thatching grass and owned cell phones and radios, not larger assets (e.g., ploughs). Their low social capital included limited participation in community groups, including informal savings clubs.

These households had limited involvement in arable agriculture and animal husbandry, which they attributed to a lack of interest, insufficient rainfall, limited arable land, and insufficient income to purchase inputs. Given this limited involvement, they faced limited production risks. However, they faced infrastructure impacts, with their traditional homes being less resistant to damage from floods, strong winds, etc. They reported the experience of floods.

\section{2) SKILLED, OFF-FARM HOUSEHOLDS WITH VERY LOW RISK}

Households in cluster 2 had high human, social, and physical capital and faced limited exposure and impacts, and therefore they had very low risk. These were newer, male-headed households, most $(87 \%)$ of which were in the wet site.

This cluster's high human capital was reflected in more educated household heads and the number of local, off-farm income sources. The wet site's neighboring tea and timber plantations provided some employment, with people also self-employed as local artisans, retailers, etc. These households do not receive remittances, an indicator of low financial capital. They had low natural capital, specifically related to NTFPs that were less available in the wet site. These newer households may also be less interested in, and knowledgeable 
of, the use and sale of NTFPs. These households had limited involvement in land-based livelihoods, with households of this archetype stating that they "don't like livestock." Limited access to arable and grazing land may be a restriction, with the village chief having reallocated land for settlement (community workshops). These households had good physical capital with more modern houses, suggesting the means to purchase building materials, aided by the site's proximity to urban centers. Participation in community-based groups and informal savings clubs contributed to households' social capital.

Given their limited involvement in land-based livelihoods, these households were less affected by production shocks. They also reported limited infrastructure damage, related to their sturdier homes. These more recently established households may be in areas with a gentler gradient (i.e., the recently reallocated land described above), making them less susceptible to damage from runoff (community workshops). This may explain the limited reporting of floods.

\section{3) CAPITAl-Diverse householdS WiTH LOW RISK}

Cluster 3's households had a diverse capital portfolio, faced low risk, were predominantly $(77 \%)$ located in the wet site, and were mostly female headed.

This cluster consisted of smaller households with labor constraints and limited involvement in local, off-farm livelihoods, suggesting low human capital. Regular remittances indicated high financial capital. The male household head had most likely migrated, remitting regularly but leaving the de facto female-headed household labor constrained. These labor constraints may explain this cluster's limited reliance on NTFPs and diverse water sources (i.e., low natural capital). These households may also have lower water requirements given their smaller size and limited involvement in land-based livelihoods. NTFPs were also less available in the wet site. These households have high natural capital in terms of private tree crops (i.e., exotic fruit trees) that grow well in the wet site and are possibly less labor intensive than cash crops. These households owned higher-value household assets (e.g., refrigerators) and had sturdier houses. Access to regular remittances and the wet site's proximity to urban centers may enable investments in physical capital. This cluster also had high social capital.

Although these households engaged in arable agriculture, cultivating fields and home gardens, this cluster was not defined by high or low agricultural impacts. Their tree crops may be less susceptible than cash crops to climatic variations and extremes. As they were not actively engaged in animal husbandry, these households faced limited exposure and impacts through livestock. They reported limited infrastructure impacts, probably linked to their sturdier houses and limited experience of floods.

\section{4) FARMING HOUSEHOLDS WITH LIMITED CAPITAL AND VERY HIGH RISK}

The households in cluster 4 were capital constrained in most aspects other than natural capital. They were very high-risk farming households, $66 \%$ of which were in the wet site, making this the most cross-cutting cluster in terms of the proportion of households per site.

The low levels of education of the household head and limited local employment suggested low human capital. These households tended not to have remitting migrants, with one household explaining that although members had migrated, they were still looking for work. As such they had low financial capital. Their high natural capital was reflected in their use of diverse water sources for irrigation and household consumption, and their ownership of private tree crops. However, these households did not engage in the use and sale of NTFPs. These natural capital patterns were most likely related to the wet site, which is better suited to the cultivation of exotic fruit trees and had more diverse water sources and lower NTFP availability. This cluster was also characterized by low physical and social capital. The former related specifically to limited household equipment, with households owning lower-value equipment.

These households engaged in, and experienced impacts associated with, arable agriculture. They did not engage in animal husbandry, attributing this to money and time constraints. As such they reported no impacts related to livestock. These households reported infrastructure damage but were not noted for having informally constructed, less sturdy homes. This suggests the damage was to infrastructure such as fencing and irrigation equipment. Flood experience was commonly reported, unlike the other wet-site-dominated clusters.

\section{5) PASTORALIST HOUSEHOLDS WITH LIMITED CAPITAL AND VERY HIGH RISK}

Cluster 5 represented capital-constrained households who faced very high risk associated with their involvement in animal husbandry. These households were all in the dry site. The cluster showed no patterns related to the age of the household or the gender of the household head.

This cluster had low human capital with limited engagement in local, off-farm livelihoods. These households did not have remitting migrants (i.e., low financial capital), with one household explaining that migrant members were still seeking work. They had low private natural capital in terms of tree crops, related to the site's poor agroecological conditions (community workshops). 
They had high natural capital related to NTFPs, with the dry site's communal rangelands providing access to NTFPs, while the Mutale River allows for fishing. Households reported selling bushmeat (particularly mopane worms) and medicinal plants. They owned highervalue equipment (i.e., high physical capital) but had low physical capital related to their less resilient, traditionally constructed homes. This cluster had low social capital.

These pastoralist households faced impacts related to livestock. For example, during recent floods, animals grazing or drinking along the river were washed away. These households faced limited arable agriculture impacts. Although they cultivated small, winter home gardens, these could be irrigated by hand, were unaffected by summer floods, and were easier to maintain. These households reported infrastructure losses related to flooding and their less-sturdy houses. They also reported damage to their livestock enclosures.

\section{6) MOdERATE RISK DESPITE LIVELIHOOD DIVERSIFICATION AND HIGH CAPITAL}

Cluster 6 represented households with diverse capitals, engaged in off-farm and land-based livelihoods. Despite exposure and impacts in arable agriculture and animal husbandry, their capital endowments reduced their overall risk. These were older households mostly $(82 \%)$ in the dry site.

These households had good human capital, consisting of larger households with locally employed (or selfemployed) members. They had high natural capital including access to diverse water sources. They engaged in the use and sale of NTFPs, selling mopane worms, fuelwood, and thatching grass. Access to transportation assets allowed for the collection and sale of greater quantities of NTFPs. These households differed from those in the other dry-site-dominated clusters in terms of their access to private natural capital. This included indigenous fruit trees (e.g., Sclerocarya birrea and Adansonia digitata) that households had maintained on their land, with the dry site being unconducive to the cultivation of exotic fruit trees. These households had good physical capital, owning higher-value equipment and more sturdily constructed houses. Households reported owning bicycles, cars, ploughs, and wheelbarrows in addition to household and communications equipment (e.g., refrigerators and cell phones). They had high social capital.

These households engaged in mixed livestock-farming systems, cultivating fields and home gardens and owning various livestock types, including more high-value livestock (i.e., cattle, donkeys, and goats). They faced impacts in both arable agriculture and animal husbandry and reported infrastructure damage. Given their sturdier homes, the latter included flood damage to fences, irrigation equipment, etc. The dry site's larger tracts of arable land were along the river, increasing the risk of flood damage. These older, agricultural households may have better access to this limited riverfront land.

\section{Discussion}

Using a conceptual framework that combines the IPCC's most recent framework on vulnerability and climate-related risk (2014) with the SLF (DFID 1999), we identified six archetypes of climate-risk profiles of rural households across two villages. The identification of these distinct risk profiles allowed for the more systematic interpretation of the climate-related risk of rural households in dryland systems, contributing to an improved understanding of the heterogeneity of this risk (Sietz et al. 2012; Kok et al. 2016; Vidal Merino et al. 2019). Key insights relate to patterns that emerge, with the most notable being a clear site-related division in the profiles (i.e., between the wet and dry sites). Sociodemographic characteristics, specifically the age of the household and the gender of the household head, also distinguish some of the profiles. These insights provide lessons on the possible pathways, and implications, for adaptation, indicating areas where responses could be targeted (Reid and Vogel 2006; Vincent 2007).

High-risk households rely on land-based livelihoods, have limited access to off-farm income, and limited adaptive capacity. Other studies have similarly identified agriculture-oriented, resource-constrained households as more vulnerable (Sietz et al. 2012; Vidal Merino et al. 2019). Additionally, the two very high-risk clusters, one per site, reported flood-related impacts to household infrastructure and assets supporting Vincent's (2007) findings of an inverse relationship between the quality of peoples' homes and vulnerability. These clusters represent almost a third of the sample, highlighting the need to address climate-related risk. Conversely, the two lowestrisk clusters (both in the wet site) are less reliant on landbased livelihoods, have a source of off-farm income, and good physical and social capital. Although these households face low climate-related risk, they may be adversely affected by other shocks (Dercon 2002; Vincent 2007; Sietz et al. 2012; Vidal Merino et al. 2019). Our results also suggest cases where households' limited engagement in land-based livelihoods is not a function of choice but rather a reflection of weak access to land and resources (i.e., as noted in one of the midrisk clusters) (Skoufias 2003). This distinction needs to be better understood, with households who are marginalized from land-based options possibly requiring different support to those who prefer off-farm livelihoods. Our second midrisk cluster suggests the need to better understand whether 
diversification is a source of resilience or vulnerability. These households reported high hazards, exposure, and impacts, but lower risk given their diverse asset portfolio. Understanding the trade-offs between specialization and diversification, would help determine whether diversification strategies should be encouraged or whether there is the need to support specific, climate-resilient activities (Sietz et al. 2012; Kok et al. 2016).

The identified climate-risk profiles are spatially distributed, with three clusters dominated by households from the dry site and three, by households from the wet site. Certain indicators, representing the core components of risk, differ notably between the sites. For example, (i) high natural capital related to NTFPs was reported by all the dry-site clusters, whereas private tree crops are common in the wet site; (ii) exposure through animal husbandry was only reported in the dry site; (iii) infrastructural impacts were reported by all the drysite clusters, related to their traditionally constructed homes; and (iv) the experience of flooding was reported by all the dry-site clusters, but only one wet-site cluster, consisting of arable farming households with poor physical capital. The AEZ in which each village is located is most likely a key determinant of these indicator differences, and therefore of the spatial distribution of the risk profiles. Applying this cluster-based approach to more villages within the same AEZs would clarify whether the profiles are consistent across each zone, or specific to the selected sites. Other studies have noted the influence of the AEZ on patterns of vulnerability, with higher vulnerability levels associated with harsher conditions (Kok et al. 2016; Vidal Merino et al. 2019). If wider testing reveals that the profiles are specific to the site, not the AEZ, then the influence of other contextual factors needs to be explored further, with Ahsan and Warner (2014) describing vulnerability as both place and context specific. For example, while the wet-site households have better access to urban centers (and the resources and services they provide), the dry site's neighboring conservation areas provide local employment opportunities, with these factors possibly influencing the risk profiles. Applying this cluster-based approach across a spectrum of AEZs would provide useful insights into the approach's broader applicability.

The climate-risk profiles show distinctions related to the age of the household, although these are more noticeable in the dry site where the older households face lower risk. Although these households face greater exposure through their diverse livelihood strategies, their overall risk is lower given their stronger, more diverse asset portfolio (i.e., higher adaptive capacity). In their South African study, Paumgarten and Shackleton (2011) similarly noted newer households as poorer than their older counterparts. Conversely, in the wet site, newer households face the lowest risk, both in the site and overall. Although the newer households in both sites have access to an off-farm income and limited involvement in land-based livelihoods (i.e., limited exposure and impacts), they face different levels of risk given their different asset portfolios. Possible explanations for these differences, include (i) that newer households in the wet site have more educated household heads allowing them to engage in more rewarding, less climate-sensitive employment, and to invest in their asset portfolios (i.e., their adaptive capacity); (ii) that newer households in the dry site struggle to establish a livelihood and asset portfolio due to the site's remoteness and harsher conditions; (iii) that the dry site's harsher conditions hamper the intergenerational accumulation and transfer of wealth, limiting the strength of both family- and community-based kinship networks; and (iv) that the newer households in the dry site consist of Zimbabwean immigrants who may face barriers to accessing resources such as land and government pension and social grants (Sietz et al. 2011, 2012; Vidal Merino et al. 2019).

Gender of the household head is a distinguishing characteristic of the two lowest-risk clusters, both in the wet site. None of the higher-risk clusters are distinguished by this characteristic. The lowest-risk cluster includes households with a more educated, male household head. These are newer households with access to an off-farm income and a limited engagement in land-based livelihoods. Interestingly, the second-lowestrisk cluster consists of female-headed households, a group that is generally considered to be more vulnerable, with limited access to assets and alternative livelihoods (DFID 1999; Posel 2001). Here, these female-headed households face lower risk given their access to regular remittances, despite exposure through their engagement in arable agriculture. Although both these clusters face low climate-related risk, they may be vulnerable to income shocks, with the female-headed households being susceptible to risks affecting the remitting migrant. It is unclear why the gender of the household head is only a distinguishing characteristic in the wet site. This requires further investigation, including why regular remittances, an indicator of high financial capital, are only a distinguishing factor in the wet site. Households in the dry site may face barriers to migration, which need to be explored.

Patterns in the clusters' capital endowments provide insights into households' existing adaptive capacity and indicate where responses could be targeted, either to address specific gaps or to build existing capacity. Although Vincent (2007) also identified differences in households' adaptive capacity in her South African 
study, the identification of broader patterns is useful. For example, our findings suggest a link between lower risk and (i) the education of the household head and (ii) households' access to an off-farm income, calling for responses that improve human capital (Dercon 2002). These lower-risk clusters have a diverse capital portfolio, as noted by Vidal Merino et al. (2019), but specifically have high physical and social capital. While the link between off-farm income and high physical capital is intuitive, the link between this income and improved social capital is worth exploring. Social capital is generally considered the capital most accessible to the poor (DFID 1999); however, our findings indicate improved social capital with access to an off-farm income. The ability of poor households to participate in community groups is limited where groups require a membership fee (Vincent 2007). How to support these informal, savings groups to enable them to provide a diversity of households with increased adaptive and coping capacity, requires further investigation (Hahn et al. 2009). Although poor households may still benefit from family networks, reciprocity, etc., increasing natural hazards may strain social capital at a community level, leaving these households with limited alternatives. In the dry site, NTFP-related adaptation strategies may provide an alternative, particularly given the existing role of NTFPs in this site. Households would benefit from sustainable harvesting practices to avoid overharvesting in response to covariate natural hazards as well as from the development of existing and new NTFP markets (Paumgarten and Shackleton 2011).

\section{Implications for adaptation responses}

Understanding the characteristics of the risk profiles, and how these differ in terms of the core components of risk, provides insights into where adaptation responses could be targeted to reduce household-level, climaterelated risk. The profiles highlight those households requiring more immediate support, but also indicate that, given the heterogeneity of climate-related risk both within and between sites, there is the need for nuanced responses (Tschakert 2007; Sietz et al. 2011; Kok et al. 2016; Vidal Merino et al. 2019). The identification of archetypes addresses some concerns related to local, case-study-based vulnerability assessments; that is, that the specificities of each case make it difficult to draw broader conclusions (Hahn et al. 2009; Sallu et al. 2010; Kok et al. 2016). Five key implications and lessons for adaptation are discussed below.

First, high levels of climate-related risk are associated with households' engagement in land-based livelihoods. With limited options to diversify off-farm, responses are needed to reduce this risk [see "Supplemental Material
3" section (Table SM3.1) for responses proposed during the fieldwork] (Sietz et al. 2012; Vidal Merino et al. 2019). These responses need to account for site-related differences in exposure. For example, arable farmers in the wet site need technical assistance and information on measures to reduce flood damage while livestock owners in the dry site require responses that support resilient pastoral systems (Table SM3.1). Respondents suggested establishing grazing camps, with water points, to prevent free-roaming livestock being washed away by floods.

Second, given the potential contribution of off-farm employment to reducing climate-related risk, households would benefit from responses that support economic integration, skills development, and the creation of local, climate-resilient jobs (Sietz et al. 2011; Kok et al. 2016). This would benefit those households currently dependent on climate-sensitive, land-based livelihoods as well as those already engaged in off-farm activities.

Third, improved settlement planning, access to better building materials, and advice on the construction of flood-resilient infrastructure would reduce the climaterelated risk of several clusters, particularly those facing higher risk due to low physical capital (Vincent 2007).

Fourth, the clear spatial distribution of the risk profiles highlights the need to understand and address climate-related risk (and its components) at the level of households and villages (Reid and Vogel 2006; Ahsan and Warner 2014; Pachauri et al. 2014; Kok et al. 2016; Sietz et al. 2017; Vidal Merino et al. 2019). Policy and practice interventions are typically designed at a broader level; however, our results suggest that even municipal-level responses may not be sufficiently nuanced if they do not account for local-level differences (Jäger et al. 2007; Sietz et al. 2011). For the purposes of scalability, categorizing locations that show similarities in the core components of climate-related risk is recommended. A nested archetype approach, as presented by Sietz et al. (2017), would also be of value here. Sietz et al. (2017) used nested archetypes to explore the heterogeneity of the vulnerability of farming systems in the drylands of sub-Saharan Africa, and similarly noted a spatial distribution.

Finally, responses aimed at reducing household-level risk should adjust their activities according to certain household characteristics, including the age of the household and the gender of the household head. Households' demographic structure can affect their adaptive capacity (Pattanayak and Sills 2001; Vincent 2007). For example, female-headed households would benefit from responses that reduce their reliance on remittances; however, given their household and child-care responsibilities, 
these responses should be gender sensitive, acknowledging the specific challenges women and female-headed households face (Eriksen et al. 2005; Sietz et al. 2012).

\section{Conclusions}

We explored the heterogeneity of climate-related risk among rural households in two distinct agroecological zones in South Africa's Limpopo Province. Using a cluster-based approach, we identified distinct patterns of climate-related risk, associated with households' experience of climate hazards, their degree of exposure and vulnerability, and the associated impacts. The identification of a limited number of distinct, archetypical risk profiles allowed for the more systematic interpretation of the climate-related risk faced by these rural households. The resulting insights provide lessons for the development and targeting local-level, climate change adaptation responses. The clear site-related distinction between the profiles suggests that site-specific responses may be needed. Having said this, the age of the household and gender of the household head also distinguish some profiles, indicating that responses need to account for sociodemographic characteristics. Based on these insights, limited resources can be more appropriately allocated, priorities can be set, and the relevant stakeholders can be identified.

By presenting a structured way to analyze the heterogeneity of climate-related risk at the local level, this approach provides rich detail without getting caught up in the intricacies of the individual household. The identified profiles set a baseline against which adaptation can be monitored, while the use of selected indicators allows for cross-case comparisons. The identification of distinct profiles (based on defined core components) also provides an opportunity to involve local stakeholders in discussions on responses required. Applying this approach to a greater number of households across a broader range of agroecological zones (and contexts) experiencing a different set of climaterelated hazards would help test the approach's broader applicability. This would help establish whether the six identified archetypes, and the associated recommendations, apply to a broader set of circumstances. Testing this approach with different indicators would provide further insights. Overall, this paper highlights the applicability of archetype analysis as a means to explore vulnerability and risk at the household level. In doing so, it contributes to ongoing discussions on climate-related risk and adaptation in the drylands of southern Africa and more generally. Finally, it presents a way to operationalize the IPCC's revised, risk-focused climate change framework at the local level.
Acknowledgments. Thank you to the Bennde Mutale and Vondo communities for participating in the research and to the translators and enumerators for their invaluable contribution. The research was supported by South Africa's National Research Foundation (NRF) (NRF 92241), the NRF Centre of Excellence in Tree Health Biotechnology, the Global Change Institute (with funding from the Carnegie Corporation of New York) (B874.R01), the University of the Witwatersrand, and the Center for International Forestry Research. Declarations of interest: none. Compliance with ethical standards: The Research Office of the University of the Witwatersrand granted the ethical clearance to conduct the research (H120803). The relevant local authorities granted permission to conduct the research and formal, free, prior, and informed consent was obtained from all participants. Anonymity was assured. All ethical standards were adhered to.

\section{REFERENCES}

Adger, W. N., N. Brooks, G. Bentham, M. Agnew, and S. Eriksen, 2004: New indicators of vulnerability and adaptive capacity. Tyndall Centre for Climate Change Research Tech. Rep. 7, 128 pp., http://citeseerx.ist.psu.edu/viewdoc/download? doi $=10.1 .1 .112 .2300 \&$ rep $=$ rep $1 \&$ type $=$ pdf.

Ahsan, M. N., and J. Warner, 2014: The socioeconomic vulnerability index: A pragmatic approach for assessing climate change led risks-A case study in the south-western coastal Bangladesh. Int. J. Disaster Risk Reduct., 8, 32-49, https:// doi.org/10.1016/j.ijdrr.2013.12.009.

Anderberg, M. R., 1973: Cluster Analysis for Applications. Academic Press, 359 pp., https://doi.org/10.1016/c2013-0-06161-0.

Ansoms, A., and A. McKay, 2010: A quantitative analysis of poverty and livelihood profiles: The case of rural Rwanda. Food Policy, 35, 584-598, https://doi.org/10.1016/j.foodpol.2010.06.006.

Birkmann, J., 2007: Risk and vulnerability indicators at different scales: Applicability, usefulness and policy implications. Environ. Hazards, 7, 20-31, https://doi.org/10.1016/j.envhaz.2007.04.002.

Blackie, R., and Coauthors, 2014: Tropical dry forests: The state of global knowledge and recommendations for future research. CIFOR Discussion Paper 2, 37 pp., https://doi.org/10.17528/ cifor/004408.

Chilonda, P., and J. Otte, 2006: Indicators to monitor trends in livestock production at national, regional and international levels. Livest. Res. Rural Dev., 18, 117, http://www.lrrd.org/ lrrd18/8/chil18117.htm.

Cooper, P. J. M., J. Dimes, K. P. C. Rao, B. Shapiro, B. Shiferaw, and S. Twomlow, 2008: Coping better with current climate variability in the rain-fed farming systems of sub-Saharan Africa: An essential first step in adapting to future climate change? Agric. Ecosyst. Environ., 126, 24-35, https://doi.org/ 10.1016/j.agee.2008.01.007.

Dazé, A., K. Ambrose, and C. Ehrhart, 2009: Climate Vulnerability and Capacity Analysis Handbook. CARE International, 52 pp., https://www.care.org/sites/default/files/documents/ CC-2009-CARE_CVCAHandbook.pdf.

de Jalón, S. G., A. Iglesias, and M. B. Neumann, 2018: Responses of sub-Saharan smallholders to climate change: Strategies and 
drivers of adaptation. Environ. Sci. Policy, 90, 38-45, https:// doi.org/10.1016/j.envsci.2018.09.013.

Dercon, S., 2002: Income risk, coping strategies, and safety nets. World Bank Res. Obs., 17, 141-166, https://doi.org/10.1093/ wbro/17.2.141.

DFID, 1999: Sustainable livelihoods guidance sheets. Department for International Development, 150 pp., https:/www.livelihoodscentre.org/ documents/114097690/114438878/Sustainable + livelihoods + guidance + sheets.pdf/594e5ea6-99a9-2a4e-f288-cbb4ae4bea8b?t=1569512091877.

Eakin, H., and L. A. Bojórquez-Tapia, 2008: Insights into the composition of household vulnerability from multicriteria decision analysis. Global Environ. Change, 18, 112-127, https://doi.org/10.1016/j.gloenvcha.2007.09.001.

Eriksen, S., K. Brown, and P. M. Kelly, 2005: The dynamics of vulnerability: Locating coping strategies in Kenya and Tanzania. Geogr. J., 171, 287-305, https://doi.org/10.1111/ j.1475-4959.2005.00174.x.

FAO, 2003: Compendium of agricultural-environmental indicators: $1989-91$ to 2000 . United Nations, 36 pp., accessed 13 March 2019, http://www.fao.org/fileadmin/templates/ess/ documents/other_statistics/compendium/agr_env_indic.pdf.

Funk, C., and Coauthors, 2015: The climate hazards infrared precipitation with stations-A new environmental record for monitoring extremes. Sci. Data, 2, 150066, https://doi.org/ 10.1038/sdata.2015.66.

Füssel, H. M., and R. J. T. Klein, 2006: Climate change vulnerability assessments: An evolution of conceptual thinking. Climatic Change, 75, 301-329, https://doi.org/10.1007/s10584006-0329-3.

Gautam, Y., and P. Andersen, 2016: Rural livelihood diversification and household well-being: Insights from Humla, Nepal. J. Rural Stud., 44, 239-249, https://doi.org/10.1016/ j.jrurstud.2016.02.001.

Gbetibouo, G. A., C. Ringler, and R. Hassan, 2010: Vulnerability of the South African farming sector to climate change and variability: An indicator approach. Nat. Resour. Forum, 34, 175-187, https://doi.org/10.1111/j.1477-8947.2010.01302.x.

Günther, I., and K. Harttgen, 2009: Estimating households' vulnerability to idiosyncratic and covariate shocks: A novel method applied in Madagascar. World Dev., 37, 1222-1234, https://doi.org/10.1016/j.worlddev.2008.11.006.

Hahn, M. B., A. M. Riederer, and S. O. Foster, 2009: The livelihood vulnerability index: A pragmatic approach to assessing risks from climate variability and change-A case study in Mozambique. Global Environ. Change, 19, 74-88, https://doi.org/10.1016/ j.gloenvcha.2008.11.002.

Heltberg, R., S. P. Bennett, and J. S. Lau, 2009: Addressing human vulnerability to climate change: Toward a "no-regrets" approach. Global Environ. Change, 19, 89-99, https://doi.org/ 10.1016/j.gloenvcha.2008.11.003.

International Food Policy Research Institute, 2015: Agro-ecological zones for Africa south of the Sahara v3. Project HarvestChoice, Harvard Dataverse, accessed 21 October 2019, https://doi.org/ 10.7910/DVN/M7XIUB.

Jäger, J., and Coauthors, 2007: Vulnerability of people and the environment: Challenges and opportunities. Global Environmental Outlook 4-Environment for Development, UNEP Progress Press, 301-360, https://www.sei.org/publications/vulnerabilitypeople-environment-challenges-opportunities/.

Janssen, P., C. Walther, and M. Lüdeke, 2012: Cluster analysis to understand socio-ecological systems: A guideline. PIK Rep. 126, 97 pp., https://www.academia.edu/23808568/Cluster_ Analysis_to_Understand_Socio-Ecological_Systems_A_Guideline.
Karim, A., 2018: The household response to persistent natural disasters: Evidence from Bangladesh. World Dev., 103, 40-59, https://doi.org/10.1016/j.worlddev.2017.10.026.

Kok, M., M. Lüdeke, T. Sterzel, P. Lucas, C. Walther, P. Janssen, D. Sietz, and I. de Soysa, 2010: Quantitative analysis of patterns of vulnerability to global environmental change. Netherlands Environmental Assessment Agency (PBL), accessed 21 October 2019, https://www.pbl.nl/en/publications/Quantitative-analysispatterns-vulnerability-global-environmental-change.

- — , P. Lucas, T. Sterzel, C. Walther, P. Janssen, D. Sietz, and I. de Soysa, 2016: A new method for analyzing socioecological patterns of vulnerability. Reg. Environ. Change, 16, 229-243, https://doi.org/10.1007/s10113-014-0746-1.

Leichenko, R., and K. O'Brien, 2002: The dynamics of rural vulnerability to global change: The case of southern Africa. Mitigation Adapt. Strategies Global Change, 7, 1-18, https:// doi.org/10.1023/A:1015860421954.

Luers, A. L., D. B. Lobell, L. S. Sklar, C. L. Addams, and P. A. Matson, 2003: A method for quantifying vulnerability, applied to the agricultural system of the Yaqui Valley, Mexico. Global Environ. Change, 13, 255-267, https://doi.org/10.1016/S09593780(03)00054-2.

McSweeney, K., 2005: Natural insurance, forest access, and compounded misfortune: Forest resources in smallholder coping strategies before and after Hurricane Mitch, northern Honduras. World Dev., 33, 1453-1471, https://doi.org/10.1016/ j.worlddev.2004.10.008.

Mucina, L., and M. C. Rutherford, Eds., 2011: The vegetation of South Africa, Lesotho and Swaziland. SANBI, accessed 21 October 2019, https://www.sanbi.org/documents/the-vegetation-of-southafrica-lesotho-and-swaziland-strelitzia-19/.

Oberlack, C., and Coauthors, 2019: Archetype analysis in sustainability research: Meanings, motivations, and evidence-based policy making. Ecol. Soc., 24, 26, https://doi.org/10.5751/ ES-10747-240226.

O'Brien, K., T. Quinlan, and G. Ziervogel, 2009: Vulnerability interventions in the context of multiple stressors: Lessons from the Southern Africa Vulnerability initiative (SAVI). Environ. Sci. Policy, 12, 23-32, https://doi.org/10.1016/j.envsci.2008.10.008.

Ofoegbu, C., P. W. Chirwa, J. Francis, and F. D. Babalola, 2016: Assessing forest-based rural communities' adaptive capacity and coping strategies for climate variability and change: The case of Vhembe district in South Africa. Environ. Dev., 18, 36-51, https://doi.org/10.1016/j.envdev.2016.03.001.

Orr, A., and P. Jere, 1999: Identifying smallholder target groups for IPM in southern Malawi. Int. J. Pest Manage., 45, 179-187, https://doi.org/10.1080/096708799227770.

Pachauri, R. K., and Coauthors, 2014: Climate Change 2014: Synthesis Report. Cambridge University Press, 151 pp., https:// www.ipcc.ch/site/assets/uploads/2018/02/SYR_AR5_FINAL_ full.pdf.

Pattanayak, S. K., and E. O. Sills, 2001: Do tropical forests provide natural insurance? The micro-economics of non-timber forest product collection in the Brazilian Amazon. Land Econ., 77, 595-612, https://doi.org/10.2307/3146943.

Paumgarten, F., and C. M. Shackleton, 2011: The role of non-timber forest products in household coping strategies in South Africa: The influence of household wealth and gender. Popul. Environ., 33, 108-131, https://doi.org/10.1007/s11111-011-0137-1.

Pelling, M., and C. High, 2005: Understanding adaptation: What can social capital offer assessments of adaptive capacity? Global Environ. Change, 15, 308-319, https://doi.org/10.1016/ j.gloenvcha.2005.02.001. 
Posel, D. R., 2001: Who are the heads of household, what do they do, and is the concept of headship useful? An analysis of headship in South Africa. Dev. South. Africa, 18, 651-670, https://doi.org/10.1080/03768350120097487.

Reid, P., and C. Vogel, 2006: Living and responding to multiple stressors in South Africa-Glimpses from KwaZulu-Natal. Global Environ. Change, 16, 195-206, https://doi.org/10.1016/ j.gloenvcha.2006.01.003.

Reynolds, F. A., and Coauthors, 2007: Global desertification: Building a science for dryland development. Science, 316, 847-851, https://doi.org/10.1126/science.1131634.

Safriel, U., and Z. Adeel, 2008: Development paths of drylands: Thresholds and sustainability. Sustainability Sci., 3, 117-123, https://doi.org/10.1007/s11625-007-0038-5.

Sallu, S. M., C. Twyman, and L. C. Stringer, 2010: Resilient or vulnerable livelihoods? Assessing livelihood dynamics and trajectories in rural Botswana. Ecol. Soc., 15, 3, https://doi.org/ 10.5751/ES-03505-150403.

Sietz, D., M. K. B. Lüdeke, and C. Walther, 2011: Categorization of typical vulnerability patterns in global drylands. Global Environ. Change, 21, 431-440, https://doi.org/10.1016/ j.gloenvcha.2010.11.005.

, S. E. Mamani Choque, and M. K. B. Lüdeke, 2012: Typical patterns of smallholder vulnerability to weather extremes with regard to food security in the Peruvian Altiplano. Reg. Environ. Change, 12, 489-505, https://doi.org/10.1007/s10113011-0246-5.

, J. C. Ordoñez, M. T. J. Kok, P. Janssen, H. B. M. Hilderink, P. Tittonell, and H. Van Dijk, 2017: Nested archetypes of vulnerability in African drylands: Where lies potential for sustainable agricultural intensification? Environ. Res. Lett., 12, 095006, https://doi.org/10.1088/1748-9326/aa768b.

, U. Frey, M. Roggero, Y. Gong, N. Magliocca, R. Tan, P. Janssen, and T. Václavík, 2019: Archetype analysis in sustainability research: Methodological portfolio and analytical frontiers. Ecol. Soc., 24, 34, https://doi.org/10.5751/ES-11103240334.

Skoufias, E., 2003: Economic crises and natural disasters: Coping strategies and policy implications. World Dev., 31, 1087-1102, https://doi.org/10.1016/S0305-750X(03)00069-X.
Statistics South Africa, 2014: Census 2011_Provincial profile: Limpopo. SSA Rep. 03-01-78, 58 pp., http://www.statssa.gov.za/publications/ Report-03-01-78/Report-03-01-782011.pdf.

Thivhafuni, P., 2015: Limpopo-Provincial Climate Change Response Strategy (2016-2020). Limpopo Department of Economic Development Environment and Tourism, 120 pp., accessed 21 October 2019, http:/www.ledet.gov.za/wp-content/uploads/ 2016/11/Limpopo_Climate_Change-Response_Strategy_-2016_ 2020_Final.pdf.

Tschakert, P., 2007: Views from the vulnerable: Understanding climatic and other stressors in the Sahel. Global Environ. Change, 17, 381-396, https://doi.org/10.1016/j.gloenvcha.2006.11.008.

Turnbull, M., and E. Turvil, 2012: Participatory capacity and vulnerability analysis: A practitioner's guide. Oxfam International, accessed 21 October 2019, https://policy-practice.oxfam.org.uk/ publications/participatory-capacity-and-vulnerability-analysisa-practitioners-guide-232411.

Turpie, J., and M. Visser, 2013: The impact of climate change on South Africa's rural areas. Submission for the 2013/14 Division of Revenue, Financial and Fiscal Commission, 100-162, http:// www.ffc.co.za/docman-menu-item/commission-submissions/300chapter-4-impact-of-climate-change-on-south-africas-rural-areas2.

Venter, S. M., and E. T. F. Witkowski, 2013: Fruits of our labour: Contribution of commercial baobab (Adansonia digitata L.) fruit harvesting to the livelihoods of marginalised people in northern Venda, South Africa. Agroforestry Syst., 87, 159-172, https://doi.org/10.1007/s10457-012-9532-6.

Vidal Merino, M., D. Sietz, F. Jost, and U. Berger, 2019: Archetypes of climate vulnerability: A mixed-method approach applied in the Peruvian Andes. Climate Dev., 11, 418-434, https://doi.org/ 10.1080/17565529.2018.1442804.

Vincent, K., 2007: Uncertainty in adaptive capacity and the importance of scale. Global Environ. Change, 17, 12-24, https:// doi.org/10.1016/j.gloenvcha.2006.11.009.

Vogel, C., and K. O'Brien, 2004: Vulnerability and global environmental change: Rhetoric and reality. AVISO, 13, 1-8, http://hdl.handle.net/10625/39859.

Wunder, S., A. Angelsen, and B. Belcher, 2014: Forests, livelihoods, and conservation: Broadening the empirical base. World Dev., 64, S1-S11, https://doi.org/10.1016/j.worlddev.2014.03.007. 